\title{
Discussion on Transition of Public Servant Appointment System
}

\author{
Lihe Wang \\ Qilu University of Technology \\ School of Literature and Law \\ Ji'nan, China 250308
}

\begin{abstract}
The public servant appointment system varies with the social development and it has distinct characteristics of the era and is closed combined with the historical background. Especially after China's reform and opening up, the economy develops at a rapid speed. The public servant appointment system needs to be perfected as well. Only the public servant appointment system is adjusted continuously, can the public servant human resources be developed unceasingly, and can the quality of public servants and administrative efficiency of state organs be improved, and serve the people better and flourish the country.
\end{abstract}

Keywords—public servants; appointment system; transition

\section{INTRODUCTION}

Public servant appointment system varies with the economic development and social reforms, Economic basis determine the superstructure which includes political superstructure and ideology superstructure. The perfection of political superstructure is the key for perfecting the superstructure, public servants are footstones of the superstructure, the running of state machinery is stiff, yet the public servant appointment is flexible, to perfect the public servant appointment system will play a profound role in improving the superstructure, pushing the economic development and promoting the country's flourishing.

\section{Changes of OfFicial SElEction Systems in}

\section{ANCIENT CHINA-PREDECESSOR OF PUBLIC SERVANTS}

Economic basis determine the superstructure, official selection system was established with the formation of private ownership and state systems, and the establishment of state systems symbolized the birth of official system and selection system. Marxist state concept defines a country like this: the state is an outcome irreconcilable due to the class contradictions. It turns out that the state is a social public power organization that it is used by the class which predominate in economy to protect and realize the class benefits of its own. As a social public power organization, it has to depend on all social resources usable to create a space of power of its own and also use the power to capture all resources of the society. Therefore, there were great differences in the official selection systems in ancient China, which were also inherited and lasted so as to expand the power castle, namely strengthen the centralization. The official selection system was an important measure to guarantee the feudal system, besides, the selection standards were improved gradually, starting from initial family background to excellent in moral and knowledge, it has been becoming just and fair gradually. Starting from Xia Dynasty, the first dynasty in China, the official selection system started a long journey in the country. During the dynasties of Xia, Shang and Zhou, the official selection systems were mainly hereditary system which was characterized of hereditary, unity of royalty and clan power. In Qin Dynasty, titles of nobility were granted as per military exploits, at the time the hereditary system was broke; In Han Dynasty, going with the development of economy, politics and culture, a whole set of official selection system were established, which were represented by election system and Zhengpi System; in dynasties of Wei, Jin, South and North, Nine-rank system which stressed family pedigree predominated gradually, finally falling behind the System of Dominant Family, which was thought a reversal of the official selection system. The imperial examination system in Tang Dynasty was great progress for the official selection system in ancient China, which was adopted in many dynasties that followed, and it is also an important method and method to select public servants currently in China. It turns out that the transition and development of systems are spiral, and the system development is in similarity and inheritance. Therefore, the public servant system is not faked or produced at random, which can be traced back to the ancient times.

\section{INTEGRATION OF EAST AND WEST OFFICIAL \\ SELECTION SYSTEMS - PRIMARY STATUS OF PUBLIC SERVANT System AT THE STAGE OF NATIONAL GOVERNMENT OF CHINA}

During studying abroad, Mr. Sun Yat-sen established a revolutionary political party and carefully studied the social political theories of bourgeoisie and investigated the capitalist social systems, after the Revolution in 1911, a bourgeois Government of Republic China was set up, which released Provisional Constitution of the Republic of China and established official selection systems applicable. After investigating the capitalist system of separation of three powers in the west, he borrowed favorable factors out of imperial examination system and supervisory system in the ancient political systems, raising a new concept of "Fivepower constitution", examination power, one of the five 
powers, took the examination principle as basic method and appointment system to select officials, which gradually promoted the sprout of public servant in China, and an institution, examination academy, was established to select the public servants, the public servant examination system started to be carried out throughout the country, besides, a series of rules concerning public servants were issued such as Examination Rules for Public Servant, it affirmed the public servant appointment system on laws and systems, of course, it what Mr. Sun Yat-sen learned abroad but not created at random. International study and exile brought him chances to investigate and touch the constitutional system in the Occident and Japan which developed rapidly at that time. As such, Mr. Sun Yat-sen found a way to break the system of public servants in China. It is known that some European countries and the USA were countries where bourgeois revolutions took place earlier, therefore, the constitutional system had a thick origin relations with the public servant system that suited it. So to borrow and integrate the advantages of international public servants will be beneficial for our country. At the stage of Republic China, the public servants were classified clearly and examination and Quan $\mathrm{Xu}$ were adopted to form the public servant system, which were carried out and supervised by Examination Committee and Quan Xu Dept affiliated to the examination authority of National Government, it was a reform and development on the basis of official selection systems in the previous dynasty, and it deepened the examination system and expand to employ talented people. At the stage of Nanjing National Government, the public servant examination and appoint system got further developed and perfected. Main types for the public servant examination mainly include public office candidate examination, professional and technician exam and appointed personnel examination and qualification examination, the public servant appointment system has developed from the initial screening and investigation and examination system to the appointment system which has been improved greatly.

It is easy to see that the public servant appointment system at the stage of National Government of China was in the stage of transition, which played an important role in instructing the new China to exploit a public servant appointment system with Chinese characteristics after China's reform and opening up.

\section{REORGANIZATION AFTER FOUNDATION OF NEW ChINA-Initial Est ABlishment OF THE PubliC SERVANT APPOINTMENT SYSTEM}

At the initial stage after the foundation of New China, the economic construction and all kinds of other work were waiting to be done in a long period of time. Just because of the situation and causes, a great number of cadres and talents were needed for the construction of the new China. Mao Zedong ever said, "with the political lines confirmed, cadres are decisive factors", facing such as social background, multiple means and methods were adopted to appoint public servants at that time. We can image that a great number of soldiers backing from the anti-Japanese front were arranged to the central and local governments to act as public servants, soon they, acting as public servants, were devoted to the construction of the country. In addition, excellent international students were called on to back and build the country, after returning home, some international students took heavy tasks. In addition, some patriots without party affiliation from multiple parties who were noble with high prestige were appointed, which were closely related to the multi-party cooperation system initially established at that time. Seen from this point, most of the public servants were directly appointed at that time, which was supported by election system and examination system, which were necessary at that time.

No doubt, after foundation of the country, the public servant appointment system was imperfect and incomplete, and what the most important is there were no relevant laws and regulations suiting it. In addition, for the ten-year great Cultural Revolution, both the state laws and the public servant appointment are suspended and even reversed in the stage. However, after the reform of opening up, the public servant appointment system of China borrowed relevant experience and got some lessons.

\section{EXPLORATION AFTER REFORM AND OPENING UP- PUblic SERVANT APPOINTMENT SYSTEM IN THE MARKET ECONOMIC MECHANISM}

\section{A. Exploration of Public Servant Appointment System after Reform and Opening Up}

After the reform and opening up in 1978, the previous planned economic system was gradually transmitted to the market economy, and a socialist market economy system with Chinese characteristics comes into being. The economic basis determine superstructure, when the economic basis change, the superstructure shall follow it. Therefore, in order to meet the socialist development requirements with Chinese characteristics, the public servant appointment system in China shall change as well. The previous public servants are life time duty, yet it begins to change to a retirement system, which to a large extent embodies justice and fairness, and more people will have chances to serve as public servants. In the market economy, the public servant appointment system has an obvious feature: there are corresponding laws and regulations to suit it, for example, 1993, Provisional Ordinance for Public Servants was promulgated in the country, which was the first law concerning personnel management in new China, which symbolized that the public servants management in China had taken important step on the way to science, legalization and standardization. In 2005, the first Law of Public Servants was released in China, which normalized the public servant management system, achieving the connection with existing cadre management system, perfect the public servant management mechanism, establishing a metabolism mechanism on the public servant appointment, competition mechanism, rights protection mechanism and supervision mechanism and it was an important measure to deepen the reform of cadre personnel system. 


\section{B. Main Appointment Modes for Public Servant Management}

At present, there are four types of public servant appointment systems in the country: election system, appointment system, engagement system and examination system

1) Election system: It means a system through which public servants are elected from down to up according to legal democratic procedures, which mainly applies to leadership of states and parties, compared to other systems, its advantages are equal chance, open election, decided by the people; yet its disadvantages are limited scope, imperfect elective procedures and lack of supervision mechanism.

2) Appointment system: It is a system through which public servants are appointed from up to down according to the administration authority of public servants. Its advantages are abiding by the central authority, uniform in government decree, high efficiency; yet it may cause the lack of independence of local officials and petticoat influence due to personal factors.

3) Examination system: It is a system through which public servants are selected according to the enrollment requirements open to the public, uniform, standard and open examination, and the results will be based on for enrollment. Its advantages mainly include open and transparent in procedures, excellent talents are selected to the government system to expand the social basis of political rule.

4) Engagement system: It is a system through public servants are engaged regularly through signing contracts with government agencies, with special features, it selects talents excellent in both political integrity and ability for management duties, which is consistent with the saying "a good scholar can become an official; he who excels in study can follow an official career". It has features as market competition, open and flexible, though it is not the main stream but improves the social levels in knowledge and profession, lowers the governmental costs. No doubt, it has defects as well such as limited scope, imperfect examination mechanism or bad practice as private connection for bad conducts.

Currently the four systems have promoted the governments to change concepts in personnel, which makes it better to optimize the public servant teams and upgrade the overall quality, doing good to keep the society fair and just and secure the county in a long term development and booming.

\section{CONCLUSION}

The public servant appointment system in China has been lasting and developing, and it has distinct characteristics of the times and is closed related to the historical background. Only continuous adjustment is made to improve the public servant appointment system can the public servant resources be developed unceasingly and raise the quality of public servant teams and the efficiency of state agencies, and improve the images of state agencies in the eyes of the people so as to better serve the people and boom the country.

\section{REFERENCES}

[1] East Law Review, Public Servant System in China: Historical Changes, Status Quo and Development, Dec 30, 2009.

[2] Digest News, Great Importance of Law on Public Servants, Nov 17, 2005

[3] Ji Peirong, Wang Lihe, Analysis of Engagement System in the Laws on Public Servants, Journal of Political Science and Law, Period V, Oct 2007.

[4] He Yuxian, Comparative Analysis of Multiple Appointment Modes of Public Servants in China, Journal of Educational Institute of Jilin Province, Nov 2013. 